\title{
АГРО-ТЕХНО-ЭКОНОМИЧЕСКАЯ ЭФФЕКТИВНОСТЬ РОТАЦИОННОЙ САДОВОЙ КОСИЛКИ
}

\author{
А.К. Апажев, Ю.А. Шекихачев, Л.М. Хажметов \\ Кабардино-Балкарский государственный аграрный университет \\ им. В.М. Кокова \\ Российская Федерация, 360031, КБР, г. Нальчик, пр. им. Ленина, $1^{\text {в }}$ \\ E-mail: shek-fmep@mail.ru
}

Наибольшей перспективой для почвозащитной системы ведения горного садоводства обладает мульчирующая система ухода за почвой. При этом в качестве мульчматериала следует использовать скошенную и измельченную растительность растительность. Наибольший эффект от мульчирования растительности в условиях горного садоводства достигается при применении косилочных устройств, использование которых позволяет наиболее полно реализовать дерново-перегнойную систему содержания почвы в садах.

Для реализации указанной системы содержания почвы в садах нами разработана и испытана ротационная косилка эшелонированного резания.

В результате измерения физических характеристик почвы и обеспеченности ее влагой установлено, что насыщенный корнями слой почвы на глубине 30 см самый рыхлый при мульчировании. В относительном выражении увеличение содержания влаги в метровом слое почвы террас выше на $24,6 \%$, чем без применения предлагаемых агротехнических приемов. Мульчирование снижает сток в $3 \ldots 4,5$ раза, а смыв в $3,8 \ldots 6$ раз. Использование разработанной косилки обеспечивает: экономический эффект за счет повышения урожайности и качества плодов в размере 5,52 тыс. руб/га; чистый дисконтированный доход за период эксплуатации (5 лет) в 11866,42 тыс. руб. на площади 100 га; снижение себестоимости выполнения технологического процесса в 2 раза; снижение трудовых затрат в 1,5 раза; снижение эксплуатационных затрат в 2,1 раза.

Ключевые слова: садоводство, почва, растительность, косилка, мульчирование, эффективность.

Введение. Сегодня и на ближайшую перспективу крупной проблемой горного садоводства и важным резервом в решении продовольственной проблемы является эффективное использование склоновых земель горных регионов под плодовые насаждения. Поэтому разработка противоэрозионных ресурсосберегающих технологических процессов и технических средств для их выполнения, значительно снижающих трудоемкость основных работ в горном садоводстве и предотвращающих эрозионные процессы, является актуальной проблемой.

Цель работы: проверка в производственных условиях результатов теоретических и экспериментальных исследований, правильности выбора оптимальных значений основных параметров, надежности и работоспособно- 
сти опытного образца и совершенствования конструктивных, кинематических и технологических параметров ротационной косилки эшелонированного резания.

Объект и методы исследования: разработанная конструкция ротационной косилки [1-3] в соответствии со стандартными методиками была испытана в условиях садового участка ОПХ «Затишье» ФГБНУ «СевероКавказский научно-исследовательский институт горного и предгорного садоводства».

Результаты и обсуждение. Для оценки агротехнической эффективности террасирования и мульчирования почвы были заложены и проведены опыты на террасированном склоне крутизной $10 \ldots 12^{\circ}$ в следующих вариантах: мульчирование почвы междурядий растительностью (вариант 3), террасирование склона без мульчирования полотна террасы (вариант 2). Данные варианты сравнивались с участками нетеррасированного склона (контроль, вариант 1). Каждый вариант охватывал участок склона от водораздела до делювиального шлейфа и имел длину не менее 80 м. Ширина участков от 30 до 60 м. Склон юго-западной экспозиции занят под насаждения яблони сорта Старкримсон. Почвы склона представлены среднесмытыми лесными почвами с укороченным горизонтом А+В. С глубины 25...30 см залегает иллювиальный горизонт ВС с повышенной плотностью.

Параметры водно-физического состояния почв определяли по горизонтам через 10 см до глубины 40 см. Такая глубина отбора образцов диктуется средней мощностью почвенного покрова с малой долей или без включения обломков горных пород. При этом объемную массу почвы определяли с помощью цилиндрических колец с внутренним объемом полости, равном $100 \mathrm{~cm}^{3}$. Твердость измеряли плотномером Ревякина, а влажность - методом высушивания образцов до постоянного веса в сушильных шкафах при температуре $105^{\circ} \mathrm{C}[4-7]$.

На основании результатов теоретических и экспериментальных исследований основными параметрами опытного образца ротационной косилки эшелонированного резания были выбраны: энергетическое средство трактор МТЗ-80; скорость энергетического средства - 1,5 м/с; количество секций -2 ; количество роторов в каждой секции - 3; привод роторов - механический; диаметр ротора, м - 0,64; тип режущего элемента - плоский; количество режущих элементов, шт - 4; окружная скорость вращения роторов, об/мин - 66,6 м/с.

Производственные испытания ротационной косилки эшелонированного резания показали, что ее производительность в среднем составила 0,7 га/ч. В результате измерения физических характеристик почвы и обеспеченности ее влагой (табл. 1) установлено, что верхний 10 см слой почвы имеет наименьшую плотность под мульчирующим слоем и самую высокую на контроле (вариант 1). Насыщенный корнями слой почвы на глубине 30 см самый рыхлый в варианте 3 (мульчирование). В последнем варианте отмечено существенное разрыхление почвы на глубине 50 см. 
Таблица 1 - Изменение водно-физических свойств почвы на фоне применения почвозащитной технологии

\begin{tabular}{|c|c|c|c|c|c|c|c|c|c|}
\hline \multirow{2}{*}{$\begin{array}{c}\text { Вари- } \\
\text { анты } \\
\text { опыта }\end{array}$} & \multicolumn{8}{|c|}{ Показатели по горизонтам, см } \\
\cline { 2 - 11 } & 10 & 30 & 50 & 10 & 30 & 50 & $0-50$ & $50-100$ & $0-100$ \\
\hline 1 & 1,19 & 1,31 & 1,46 & 8,8 & 28,3 & 31,6 & 69,5 & 62,9 & 132,2 \\
\hline 2 & 1,16 & 1,28 & 1,43 & 7,9 & 27,6 & 30,0 & 84,1 & 66,9 & 149,7 \\
\hline 3 & 1,06 & 1,24 & 1,37 & 3,8 & 15,2 & 25,1 & 76,2 & 77,6 & 159,8 \\
\hline
\end{tabular}

Таким образом, даже простое террасирование способствует разрыхлению почвы, что связано с технологией сооружения террас: при напашке увеличивается мощность слоя почвы, подверженного механической обработке.

Наиболее благоприятные условия для развития корней создаются при мульчировании (вариант 3). Здесь по сравнению с контролем в корнеобитаемом слое почвы ее твердость на $21 . .57 \%$ ниже.

Определение влажности почвы после выпадения ливневых осадков показало, что во всех вариантах содержание ее было существенно выше, чем на контроле. В относительном выражении увеличение содержания влаги в метровом слое почвы террас оказалось почти на $21 \%$ выше, чем без применения агротехнических приемов.

Учет стока осадков и смыва почвы (табл. 2) свидетельствовал о том, что ведущим агроприемом в предупреждении развития эрозии почв являются мульчирование (вариант 3). В этом варианте сток оказался в 3 раза меньше, чем на контроле. На третий год после закладки опыта смыв практически прекратился.

Таблица 2 - Смыв почвы и сток осадков на участках испытаний противоэрозионных агротехнических мероприятий

\begin{tabular}{|c|c|c|c|c|c|c|}
\hline \multirow{2}{*}{$\begin{array}{c}\text { Варианты } \\
\text { опыта }\end{array}$} & \multicolumn{3}{|c|}{ Сток осадков, мм } & \multicolumn{3}{c|}{ Смыв почвы, ${ }^{3} /$ га } \\
\cline { 2 - 7 } & 2007 & 2008 & 2009 & 2007 & 2008 & 2009 \\
\hline 1 & 11,6 & 11,8 & 12,8 & 28,8 & 29,1 & 29,5 \\
\hline 2 & 6,7 & 6,3 & 5,8 & $>5$ & $>5$ & $>5$ \\
\hline 3 & 3,1 & 3,3 & 4,1 & $>5$ & $>5$ & следы \\
\hline
\end{tabular}

Анализ полученных данных показывает, что сток в варианте 2 был всего в 2 раза меньше, чем на контроле. Таким образом, можно сделать вывод о том, что террасы как противоэрозионные устройства нуждаются еще и в дополнении их агротехническими приемами для предупреждения потери осадков на сток.

Общий годовой экономический эффект от использования результатов научно-исследовательской работы складывается из экономического эффекта, получаемого за счет снижения приведенных затрат и экономического эффек- 
та, получаемого за счет повышения урожайности плодовых насаждений и качества плодов. Разработанная ротационная косилка эшелонированного резания сравнивалась с косилкой ИКС-3. Расчеты по садовому участку ОПХ «Затишье» показали, что внедрение разработанной ротационной косилки эшелонированного резания обеспечивает экономический эффект за счет повышения урожайности и качества плодов в размере 5,52 тыс. руб/га. Урожайность в среднем увеличилась на 7 ц/га.

Показатели экономической сравнительной эффективности применения предлагаемой ротационной косилки эшелонированного резания приведены в табл. 3.

Таблица 3 - Показатели экономической сравнительной эффективности применения предлагаемой ротационной косилки эшелонированного резания

\begin{tabular}{|c|c|c|c|}
\hline \multirow[b]{2}{*}{ Показатели } & \multirow{2}{*}{ 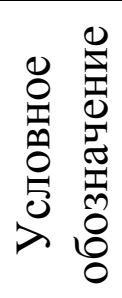 } & \multicolumn{2}{|c|}{ Вариант } \\
\hline & & $\begin{array}{l}\text { предла- } \\
\text { гаемый }\end{array}$ & базовый \\
\hline Годовой объем работ, га & $N$ & 100 & 100 \\
\hline $\begin{array}{l}\text { Чистый дисконтированный доход (эффект) } \\
\text { за весь период эксплуатации, тыс.руб. }\end{array}$ & $\Pi_{C P}$ & 11866,42 & 10859,37 \\
\hline $\begin{array}{l}\text { Единовременные капитальные вложения, } \\
\text { тыс.руб. }\end{array}$ & $K$ & 25,0 & 76,5 \\
\hline $\begin{array}{l}\text { Себестоимость процесса измельчения рас- } \\
\text { тительности ротационной косилкой, } \\
\text { тыс.руб. }\end{array}$ & $C$ & 8,517 & 18,139 \\
\hline Затраты труда на обслуживание, чел.ч & $3_{m p}$ & 455,6 & 680,0 \\
\hline Эксплуатационные затраты, тыс.руб. & $3_{Э К C}$ & 9494,8 & 20056,2 \\
\hline $\begin{array}{l}\text { Срок окупаемости капитальных вложений, } \\
\text { лет }\end{array}$ & $T_{O K}$ & 0,01 & 0,02 \\
\hline
\end{tabular}

Проведенная технико-экономическая оценка ротационной косилки эшелонированного резания показала:

- применение ротационной косилки эшелонированного резания в технологическом процессе удаления с одновременным измельчением растительности позволяет получать чистый дисконтированный доход за период эксплуатации (5 лет) в 11866,42 тыс. руб. на площади 100 га, что на 1007,05 тыс.руб. или на 9,5\% больше базового варианта;

- себестоимость выполнения технологического процесса снизилась с 18,139 тыс.руб. до 8,517 тыс.руб. или на 9,622 тыс.руб.;

- трудовые затраты в сравнении с базовой технологией снижаются в 1,5 
раза (с 680 чел.ч до 455,6 чел.час на 100 га);

- эксплуатационные затраты по предлагаемому варианту ниже базового в 2,1 раза и составляют 9494,8 тыс.руб. При этом срок окупаемости капитальных вложений составил 0,01 года.

\section{Вывод.}

Разработанная ротационная косилка эшелонированного резания обеспечивает снижение эрозионных процессов в горном садоводстве, экономический эффект за счет повышения урожайности и качества плодов, снижение себестоимости производства продукции, трудовых и эксплуатационных затрат.

\section{Литература}

1. Косилка-измельчитель эшелонированного резания: пат. 2297131 Рос. Федерация. №2003123694/12(025113); заявл. 28.07.03; опубл. 20.04.07, Бюл. №11. 4 c.

2. Атласкиров А.М., Шекихачев Ю.А., Шомахов Л.А. Обоснование конструктивной схемы ротационной садовой косилки [Электронный ресурс] // Политематический сетевой электронный научный журнал КубГАУ. 2012. URL: http://ej.kubagro.ru/2012/05/22 (дата обращения: 20.03.2014).

3. Атласкиров А.М., Шекихачев Ю.А., Шомахов Л.А. Оптимизация параметров и режимов работы ротационной садовой косилки [Электронный ресурс] // Политематический сетевой электронный научный журнал КубГАУ. 2012. URL: http://ej.kubagro.ru/2012/05/23 (дата обращения: 20.03.2014).

4. Заславский М.Н. Эрозиоведение. М.: Высшая школа, 1985. 124 с.

5. Качинский Н.А. Физика почв. М.: Высшая школа, 1965. 323 с.

6. Шекихачев Ю.А., Шомахов Л.А. К вопросу моделирования технологической системы мульчирования растительности // Тез. докл. и сообщ. Республ. научно-практ. конф. «Наука-производству». Нальчик: ЦСУ КБАCCP, 1988. C. 16-17.

7. Шекихачев Ю.А., Шомахов Л.А. Агроэкологическое обоснование способа мульчирования растительности в условиях горного садоводства // В сб. «Актуальные проблемы экологии и охраны окружающей среды КБАССР». Нальчик: ЦСУ КБАССР, 1990. С. 96 - 101. 